\title{
Chain-store pricing and the structure of retail markets*
}

\author{
Matthew Olczak ${ }^{\dagger}$ \\ Aston Business School, Aston University, UK \\ February 2014
}

\begin{abstract}
This paper examines competition between chain-stores and independent retailers in the UK retail opticians' market. We demonstrate that the pricing policy adopted by chain-stores can determine the impact their entry has on independent retailers. Crucially, in this market the chain-store retailers set an identical national price across all local markets. Our results suggest that this pricing strategy lessens the detrimental effect competition from chain-stores has on independent retailers.
\end{abstract}

JEL Classification codes: L11, L13

Keywords: retail competition, chain-stores, national pricing

*This is a revised version of Centre for Competition Policy, UEA, Norwich, Working Paper 06-7. I would like to thank Steve Davies for providing considerable support and advice, Paul Dobson, Raffaella Sadun and Steve Thompson for their assistance and an anonymous referee for their useful suggestions. The support of the Economic and Social Research Council (UK) is gratefully acknowledged.

$\dagger$ Economics and Strategy Group, Aston Business School, Aston University, Birmingham, B4 7ET, UK. m.olczak@aston.ac.uk Tel:+441212043107 


\section{Introduction}

Chain-stores are increasingly dominating many retail markets, for example in the UK multiple retailers increased their market share from around $23 \%$ to $65 \%$ between 1950 and $1995^{1}$. In addition, the Competition Commission (2008) found that since the 1950s there has been a significant decline in the number of specialist stores. Within the policy literature this has generated some concern, in particular due to the impact on product choice and local economies ${ }^{2}$. However, as discussed below, empirical evidence on the impact chain-store entry has on smaller retailers is mixed.

This paper examines competition between chain-stores and independent retailers in the retail opticians' market in England. Deregulation of this industry in the mid 1980s brought about many significant changes, particularly the removal of restrictions on entry and advertising ${ }^{3}$. This immediately lead to rapid entry and growth of chain-store retailers, increasing their market share from $46 \%$ to $75 \%$ between 1985 and 1991 $1^{4}$. A key feature of chainstore opticians is that, like a number of other chain-store retailers ${ }^{5}$, they set a single national price ${ }^{6}$

In contrast, in other industries chain-stores tailor their prices to local market conditions 7 . This practice has raised some policy concern. For exam-

\footnotetext{
${ }^{1}$ Burt and Sparks (2003).

${ }^{2}$ See for example New Economics Foundation (2005) and House of Commons, All Party Small Shops Group (2006).

${ }^{3}$ See Davies et al. (2004, chapter 2) for a discussion of the impact deregulation had on competition.

${ }^{4}$ Fulop and Warren (1993, p.267).

${ }^{5}$ For example Tesco, the largest supermarket retailer in the UK.

${ }^{6}$ See OFT (2009), para. 31.

${ }^{7}$ For example Staples and Office Depot in the US (see Dalkir and Warren-Boulton, 1999).
} 
ple, in their 2000 investigation of the UK groceries industry, the Competition Commission was concerned over the common use at that time of price flexing, defined as: 'setting retail prices across different geographic areas in the light of competitive conditions, such variations not being related to costs 8 . One reason for their concern appears to have been the possibility of a link between price flexing and below-cost selling. The fear is that such strategies may in particular adversely effect smaller convenience stores (see also Association of Convenience Stores, 2006).

Dobson and Waterson (2005) consider the rationale for chain-stores to choose to adopt such a pricing strategy. In their theoretical model a chainstore faces competition in some local markets and enjoys a monopoly position in others. Compared to when it sets different prices across local markets, under a national pricing strategy the chain-store sets a lower price in the monopoly markets but higher prices in markets where it faces competition. They show that this can be profitable because competition in the competitive markets is dampened.

We demonstrate that whether chain-stores adopt national or local pricing strategies can affect the impact chain-store entry has on independent retailers. The starting point for our empirical analysis is a methodology developed by Bresnahan and Reiss (B\&R) (1991). This uses evidence on the relationship between the number of firms and the market size to make inferences about the degree of competition. In order to illustrate this, consider a market where at least $X$ consumers are needed to support a monopolist. If a rival was also present in the market competition would lead to prices below

\footnotetext{
${ }^{8}$ Competition Commission (2000), para. 2.409, p. 90.
} 
below the monopoly level. A fall in margins means a firm must sell to more consumers in order to break even. Consequently, a market with a total of more than $2 X$ consumers is needed to support the two competing retailers. Therefore, examining how much larger the market size needs to be to support an additional firm provides information on the intensity of competition. We draw upon a recent literature which introduces firm heterogeneity to this methodology. Dinlersoz (2004) introduces competition between chain-store and independent retailers using a vertical product differentiation framework. In the manner of $\mathrm{B} \& \mathrm{R}$ this leads to predictions on the relationship between the number of each type of retailer and market size. Dinlersoz then finds evidence consistent with these predictions in the Californian retail alcoholic beverage industry.

As discussed in the next section, the model developed by Dinlersoz fits the characteristics of the retail opticians' market in England, with one exception. The one exception is that Dinlersoz models competition between chain-stores as Cournot competition. This implies that the price a chain-store sets will vary across local markets, depending upon the number of chain-store rivals present. To fit the opticians' market, in section 2.4 we modify the Dinlersoz model to allow for chain-store national pricing strategies. Introducing national pricing leads to a revised prediction on the relationship between the number of independents and market size.

In the opticians' market, evidence consistent with the prediction under national pricing is then found in markets where chain-stores are present. This suggests that chain-stores adopting national pricing strategies helps to protect independents from the intense local competition between chains that 
would otherwise occur in markets where a number of chain-stores are present.

Unlike Dinlersoz, our sample also includes markets where no chain-stores are present. Therefore, we also test for differences in the relationship between the number of independents and market size, depending upon whether or not a chain-store is present. Here, a key issue is that chain-store entry is endogenously determined. The previous literature has dealt with this issue in a number of ways. Griffith and Harmgart (2012) treat the number of larger supermarkets as an exogenous determinant of the number of smaller 'top-up' shops, arguing that this is reasonable because typically consumers make their main purchases from larger 'one-stop' stores with smaller stores receiving any residual demand. Cleeren et al. (2008) and Toivanen and Waterson (2005) exploit the sequential order of entry in the industries they study. Our approach is closest to (Borraz et al., 2013) who use variability in the availability of permits for commercial expansion as an instrument for supermarket entry. In a similar fashion, we make use of information on the number of planning grants for retail premises that have been accepted in the preceding years. Crucially, this data is separated between grants for minor and major retail premises. Therefore, this allows us to distinguish between retail premises suitable for independents and chain-store outlets. In other settings (Igami, 2011 and Sobel and Dean, 2008), geographic affiliations have been used as an alternative instrument.

Our results provide some evidence to suggest that the nature of competition between independents is affected by whether or not chain-stores are present in the market. When no chain-store is present, competitive intensity between independents increases as the number of independents goes up. 
A related literature has examined the impact of chain-store entry on smaller stores, typically focusing on the supermarket industry. As Borraz et al. (2013) conclude, the findings from this literature on the impact chainstore entry has is mixed. For example Jia (2008) finds that the entry of Wal-Mart has a substantial negative effect on smaller discount competitors, whereas Sobel and Dean (2008) find that Wal-Mart has no long-run effect on overall small business activity. In contrast, Igami (2011) finds that entry of large supermarkets in Japan may force out other large scale competitors, but have a positive effect on smaller retailers. In line with our findings, it is argued that this is because the smaller retailers are sufficiently differentiated from the larger outlets. In contrast to these previous papers, we examine a different industry and to the best of our knowledge are the first to focus on the different effects chain-store national rather than local pricing strategies can have.

The remainder of the paper proceeds as follows: section 2 shows how the predictions of the Dinlersoz (2004) model differ when national pricing is introduced. Section 3 describes the retail opticians' market in England and section 4 examines the relationship between the number of independents and market size in markets where chain-stores are present. Section 5 then compares markets with and without chain-store presence. Finally, section 6 offers some brief conclusions and avenues for further research. 


\section{A model of retail competition}

Retail competition between chain-stores and independents will be examined using a model of vertical product differentiation based on Dinlersoz (2004). Firstly the assumptions of the model are outlined and then the number of independent outlets that can profitably operate in a local market is examined. This is shown to crucially depend upon the pricing policy adopted by chainstore retailers.

\subsection{Assumptions}

This section describes the modeling assumptions made by Dinlersoz (2004) and outlines why these assumptions are appropriate for the opticians' market in England.

Competition takes place between chain-store retailers (denoted by subscript $C$ ) and independent retailers $(I)$ within local markets which will vary in size $S$ (measured by the number of consumers). Consumers have heterogeneous tastes for quality captured by $\alpha$, which measures their marginal utility from one unit of quality. In each local market $\alpha$ is assumed to be uniformly distributed over an interval $[\underline{\alpha}, \bar{\alpha}]$ with $\underline{\alpha}>0$ and $\bar{\alpha}-\underline{\alpha}=1$. For a consumer of type $\alpha$, the utility derived from a product of quality $\theta$ sold at price $p$ is:

$$
u(p, \theta ; \alpha)= \begin{cases}\alpha \theta-p & \text { if } \alpha \theta \geq p \\ 0 & \text { otherwise }\end{cases}
$$

The quality levels of the different retail outlets $\left(\theta_{I}\right.$ and $\left.\theta_{C}\right)$ are identical within 
retailer type and exogenously determined 9 , Furthermore, the independent retailers are assumed to produce a higher quality product (i.e. $\theta_{I}>\theta_{C}$ ). Without loss of generality, this quality differential is normalised so that $\theta_{I}-$ $\theta_{C}=1$. The assumption that independent opticians supply a higher quality service could be justified in terms of a more personal service, with consumers benefiting from repeated interaction with the same practitioner. In fact, one of the concerns of opponents of deregulation was a reduction in service quality 10 In addition, independent opticians have recently suggested that they were able to differentiate their product from that offered by chain-stores by offering a higher quality product and service ${ }^{11}$.

Fixed costs are denoted by $f$ and variable $\operatorname{costs} c$. In order to allow for their typically larger scale, chain-store outlets are assumed to have a total cost function $\left(C_{C}\right)$ with increasing returns to scale ${ }^{12}$ given by: $C_{C}\left(q_{C}\right)=$ $f_{C}+c_{C} q_{C}$. In contrast, the independent retailers have a total cost function $\left(C_{I}\right)$ given by: $C_{I}=f_{I}+c_{I} q_{I}^{2}$. This implies a U-shaped average cost function for the independent retailers with minimum efficient scale at

$$
q_{I}^{*}=\left(f_{I} / c_{I}\right)^{1 / 2}
$$

This is consistent with evidence that chain-store opticians have a significant

\footnotetext{
${ }^{9}$ See section 4.3 for a discussion of the impact of allowing chain-stores to set their quality level strategically.

${ }^{10}$ See for example Fulop and Warren (1993) pp. 262-64.

${ }^{11}$ OFT (2009), para. 25.

${ }^{12}$ In the Dinlersoz model increasing returns to scale are not required, however, the minimum efficient scale for chain-stores must be sufficiently greater that of the independent retailers (see Dinlersoz, 2004, p. 216). Under Cournot competition (see section 2.3) this allows the chain-stores to expand output as the market size increases. Furthermore, once national pricing is introduced in section 2.4 the predictions are unaffected by the specific chain-store cost function.
} 
scale advantage over independents in part because significant buyer power enables them to obtain lower cost from suppliers ${ }^{13}$. Furthermore, figures provided below in section 3 indicate that in this market chains-stores have a much higher value of sales per store than other retailers, consistent with these being larger scale outlets.

\subsection{The number of independent outlets in a local mar- ket}

Both the number of chain-store and independent outlets in each local market are determined by the free entry equilibrium. The independent retailers are assumed to act as a price-taking competitive fringe. Evidence consistent with this assumption in the opticians' market is provided by this description of pricing following a competition authority investigation:

"... local opticians typically base their pricing on the national decisions taken by Specsavers, which is described by the parties as well as by other multiples and independent industry reports as the market leader and, as a result of its aggressive pricing strategy, the principal price-setter" 14

In section 5 we will test to see whether Specsavers (the leading chainstore) plays a different price setting role from other chain-store retailers.

Perfect competition between the independents then means that in the free-entry equilibrium they price down to a level equal to marginal costs at the minimum efficient scale. Therefore, from (2):

$$
p_{I}^{*}=2\left(f_{I} c_{I}\right)^{1 / 2}
$$

\footnotetext{
${ }^{13}$ OFT (2009), para. 22-3.

${ }^{14} \mathrm{OFT}$ (2009), para. 31.
} 
Using (1) the consumer indifferent between the product offered by the chainstores and the independent stores has marginal utility of $\alpha^{*}$, where

$$
\alpha^{*}=p_{I}-p_{C}
$$

As in Dinlersoz (2004) each local market is assumed to be fully covered with all consumers purchasing one unit of the product from either an independent or a chain-store retailer 15 . This means that total demand in a local market is equal to $S$. In addition, we focus on parameter values such that both types of retailers are present in each market ${ }^{16}$. Consequently, consumers for which $\bar{\alpha} \geq \alpha>\alpha^{*}$ buy from an independent retailer and from (4) the local market demand for the independent retail sector is

$$
D_{I}\left(p_{I}, p_{C}\right)=S\left(\bar{\alpha}-p_{I}+p_{C}\right)
$$

In contrast, chain-stores sell to consumers with $\alpha^{*} \geq \alpha \geq \underline{\alpha}$ and the total chain-store sector demand is given by:

$$
D_{C}\left(p_{C}, p_{I}\right)=S\left(p_{I}-p_{C}-\underline{\alpha}\right)
$$

Because the independent retailers each produce an output level which is invariant to market size (see (2)), the total number of independent retailers that can profitably operate in a market $\left(N_{I}^{*} \equiv D_{I} / q_{I}\right)$ crucially depends on

\footnotetext{
${ }^{15}$ This requires the quality level of a chain-store to be sufficiently high (but not as high as independents) so that even consumers with the lowest marginal utility $(\underline{\alpha})$ choose to buy the product (for the precise condition see Dinlersoz, 2004, footnote 8).

${ }^{16}$ This requires a sufficient degree of product differentiation (see Dinlersoz, 2004, footnote 9$)$.
} 
the total demand for the independent sector. Using (2), (3) and (5), this can be written as:

$$
N_{I}^{*}=\frac{S\left(\bar{\alpha}-2\left(f_{I} c_{I}\right)^{1 / 2}+p_{C}\right)}{\left(f_{I} / c_{I}\right)^{1 / 2}}
$$

This shows that the number of independent retailers in each local market will depend upon the price set by chain-stores $\left(p_{C}\right)$. As $p_{C}$ falls, the proportion of the market served by chain-stores increases ( $\alpha^{*}$ rises). This reduces the total demand for the independents' product and, therefore, the number of independent outlets that can profitably compete falls. As will now be demonstrated, this implies that the pricing strategy adopted by chain-stores has an important impact on the number of independent retailers. The next section summarises the case where the price a chain-store charges differs across local markets as described in detail in Dinlersoz (2004).

\subsection{Local pricing by chain-stores}

Dinlersoz assumes that all chain-stores compete a la Cournot taking the price set by the independent retailers as given. Under Cournot competition the price charged by chain-store retailers depends upon the number of chainstore rivals it faces in the local market. Therefore, chain-stores are effectively adopting local pricing strategies. From (7) it can then be shown that ${ }^{17}$.

Proposition 1. If chain-stores adopt local pricing, the number of independent outlets in the local market will increase less than proportionately with an increase in the market size, but at an increasing rate.

This is because as the market size increases chain-store entry occurs, leading to a fall in the chain-store price. Therefore, the number of chain-stores

\footnotetext{
${ }^{17}$ This is shown formally in Dinlersoz (2004, p.218), equation (4).
} 
increases less than proportionately with an increase in market size. This is the intuition underlying the $\mathrm{B} \& \mathrm{R}$ approach described in the introduction. However, the fall in the chain-store price also effects the independent retailers' share of the market. Crucially, from (6) some consumers will switch from the independents' high quality product to the chain-stores' lower quality product. Consequently, the number of independent outlets also increases less than proportionately with an increase in the market size. As the number of chainstores entering the local market continues to increase, additional chain-store entry has less of an effect on price and fewer additional consumers switch to chain-stores. Therefore, as the market size increases further the number of independent outlets can increase almost proportionately with an increase in the market size.

\subsection{National pricing by chain-stores}

We can now consider how the results of the Dinlersoz model change if the chain-stores adopt national pricing, thus making the model fit the English retail opticians' market. Suppose the chain-stores all set an identical nationally determined price. This national price will be set by a chain-store in order to maximize profits across all the local markets in which it operates. As long as the total number of markets in which the chain-store operates is sufficiently large the impact of an individual local market is negligible and the national price can be modelled as exogenously determined within a given local market. It then follows from (7) that:

Proposition 2. If chain-stores adopt national pricing strategies, the number 
of independent outlets will increase proportionately with an increase in market size, for all sizes of market.

Because both chain-stores and independent firms now set a price that is invariant in the market size, the proportion of consumers preferring chainstores to independent outlets and vice versa is fixed for all market sizes.

Comparing Propositions 1 and 2 shows that the relationship between the number of independent retailers and market size depends upon whether chain-stores adopt national or local pricing strategies. In section 4 evidence on this relationship between the number of independent retailers and market size in the English retail opticians' market will be provided. First, in section 3 , the dataset is described.

\section{The opticians' market}

The dataset was obtained in 2004 by downloading from the main online business directory ${ }^{18}$ the names and postcodes of all opticians' outlets in England ${ }^{19}$. Table 1 shows the number of outlets owned by the largest multi-store firms.

[Table 1 here]

As can be seen, there are four chains owning more than 150 stores $^{20}$. Henceforth, these four will be referred to as chain-stores and all remaining outlets

\footnotetext{
${ }^{18}$ http://www.yell.com

${ }^{19}$ We omit the City of London LAD from the empirical analysis as it is principally a business area with a very low population but a comparatively large number of opticians.

${ }^{20}$ In addition, in 2009 Dolland and Aitchison and Boots were allowed to merger by the Office of Fair Trading (see OFT, 2009).
} 
as independents (Inds):

Definition. Chain-store: an optician's store owned by Specsavers, Dolland and Aitchison, Boots or Vision Express.

Of course, this definition of a 'chain-store' is somewhat arbitrary, however, there are a number of reasons for differentiating these four from the smaller, multi-store firms. First, as shown in Table 2, all four have a national presence with multiple outlets in all regions ${ }^{21}$. In addition, as stated earlier, all four chain-stores adopt national pricing strategies.

[Table 2 here]

On the other hand, with the possible exception of Optical Express the other main multi-store firms do not have a national presence. The Optical Express chain, established in 1991, has grown rapidly, and if this continues will soon join the group of main chain-store retailers ${ }^{22}$. Second, the four chain-stores, in addition to being the largest chains are also the firms in the market with a significant brand name and prominence as a high street retailer. Despite owning only $20 \%$ of stores (Table 1 ) these four chain-stores these four accounted for $54 \%$ of sales by value ${ }^{23}$ and $75 \%$ of advertising expenditure $2^{24}$.

\footnotetext{
${ }^{21}$ Each LAD is allocated to one of 9 administrative regions covering England e.g. SouthWest or London.

${ }^{22}$ However, Optical Express at the time had less than 6 stores in two of the regions. Furthermore, figures from OFT (2009, para 39.) show that in recent years Optical Express has continued to gain market share whilst the four chain-stores have all lost market share. However, even by 2007 Optical Express still had a market share by value of $4.3 \%$, which was over a third lower than the 4th largest chain (Boots) and, therefore, arguably still remains outside the main players.

${ }^{23}$ OFT (2009), para. 39.

${ }^{24}$ UK main media advertising expenditure on opticians and eye clinics in 2001, Keynote (2002).
} 
Overall, the evidence suggests these four are the chain-stores most likely to have a significant effect on independent outlet:25.

Local markets will be defined according to Local Authority Districts (LAD). These tend to be centered on town/cities and therefore represent a reasonable approximation of the area in which consumer search behaviour takes place in the opticians' market. They are also a unit of observation for which demographic data is readily available and importantly for our methodology vary considerably in size. They have also been used to define local markets in other previous studies ${ }^{26}$.

Table 3 describes the number of opticians for all 349 LAD in our sample. The number of outlets refers to the total number of stores owned by chain-stores whereas the number of fascias refers to the number of different national chains present in a market. Therefore, for example, a market with two Specsavers stores and one Boots store has three outlets but only two fascias.

[Table 3 here]

A 'typical' LAD market contains 16 opticians' outlets: 3 chain-store and 13 independent outlets. Almost $75 \%$ of markets contain less than 20 outlets. In addition, all chain-stores have multiple outlets in one or more market.

Figure 1 shows the relationship between the total number of opticians' outlets present and the population of the local market. As we would expect, there is clearly a positive relationship.

\footnotetext{
${ }^{25}$ The definition of a chain-store will also be widened to check for robustness of the results, see footnote 30 and 39 .

${ }^{26}$ For example Toivanen and Waterson (2005) and Sadun (2013).
} 
[Figure 1 here]

Whilst chain-stores are present in most of the markets in our sample, there are 41 markets in which there are no chain-stores. As Table 4 shows the markets where no chain-stores are present tend on average to be those with a lower population, but there is a significant range of smaller markets in which a chain-store may or may not be present.

[Table 4 here]

\section{Testing the relationship between the num- ber of independent retailers and market size}

\subsection{Econometric specification}

Propositions 1 and 2 suggest that the relationship between the number of independents and market size will differ depending on whether the chain-stores in the market adopt local or national pricing. The following econometric specification will allow a simple test of this proposition:

$$
\log \left(\text { NInds }_{i}\right)=C+\alpha \log \left(\text { Population }_{i}\right)+\left(X_{i}\right)^{\prime} \beta+\epsilon_{i}
$$

where the subscript i refers to an LAD market, NInds $s_{i}$ is the number of independent outlets, Population Pis $_{i}$ the LA population and $X_{i}$ is a vector of demographic variables described in Table 5 below. The error term $\epsilon_{i}$ is assumed to be independent across LAD markets. The model will be estimated using OLS and the use of the constant elasticity model means that 
the estimated coefficients show the proportional change in NInds for a given change in the explanatory variable. This allows a simple test of the differing predictions of Proposition 1 and 2. If $\hat{\alpha}<1$ the number of independent outlets increases less than proportionately with an increase in market size, consistent with local pricing (Proposition 1). In contrast, if $\hat{\alpha}=1$ the number of independent outlets increases proportionately with an increase in market size, consistent with national pricing (Proposition 2).

\subsection{Demographic variables}

The use of LAD markets allows the data on the number of outlets to be matched with census demographic data, including importantly population as a measure of market size, the number of planning applications previously granted to capture the availability of suitable retail outlets and a range of other variables that can then be used to control for cost and other possible demand differences between markets. Table 5 describes all the demographic variables that will be used 27 .

[Table 5 here]

Crucially for the empirical analysis below, the planning data distinguishes between major and minor developments where the latter is defined as a site above 1000 square meter ${ }^{28}$. It is clear that major retail developments will be

\footnotetext{
${ }^{27}$ Planning grants data is from the Office of the Deputy Prime Minister (ODPM). All the other variables are for 2001 except the wage data which is for 2005. Data Sources: Wage variable: Annual Survey of Hours and Earnings 2005, http://www.statistics.gov. uk/downloads/theme_labour/ASHE_2005/2005_res_la.pdf. All other variables: Census 2001, http://www.statistics.gov.uk/census2001/census2001.asp

${ }^{28}$ See Sadun (2013) for further details on the UK planning policy and this data.
} 
the prime location for chain-store opticians' outlet:29, whereas, as discussed earlier, the much smaller scale of independents means that only minor retail developments are appropriate locations for them. Density allows for the possibility that more densely populated areas may attract additional opticians' outlets, perhaps as they act as centre for retail activity and thus attract customers from outside the LAD. The inclusion of age controls for the likelihood that the demand for opticians' services is higher, and typically more complex sight problems exist, amongst older people. The wage variable is included as a control variable, but has two possible interpretations as it could either reflect firms' cost differences between markets or higher demand due to a more affluent population. Income support claimants are entitled to a National Health Service voucher which provides the recipient with a free sight test and discounted spectacles or contact lenses. Therefore, it is possible that demand could be higher in LADs with more income support claimants. We might expect urban LADs to attract more opticians. Finally, the travel variable captures increased demand from outside the LAD and proxies for significant business and retail districts.

\subsection{Results}

The specification given in (8) will now be estimated for the 308 local markets where one or more chain-store is present.

[Table 6 here]

${ }^{29} \mathrm{See}$ for example http://www.insidermedia.com/insider/north-west/
78166-specsavers-unveiled-latest-merseyway-tenant.


A t-test shows that there is no evidence that the coefficient on $\log$ (Population) is less than one. Instead, consistent with chain-store national pricing strategies, the evidence suggests that the number of independent outlets increases proportionately with an increase in market size (Proposition 2) ${ }^{30}$. This suggests that national pricing strategies can help to protect independents from the intense competition between chains that would otherwise occur in markets where several chains operate.

In addition, the results show that the other demographic variables also affect the number of independent retailers. A previous high number of minor retail grants has a positive effect on the number of independents31. Likewise, markets with an older population have more independent outlets, suggesting demand is higher in these markets. Finally, the number of independent outlets is also increasing in both the average wage of the LAD population and the proportion of income support claimant: 32

Dinlersoz (2004, pp. 221-2) discusses the fact that his model could be extended to allow for quality enhancing investments by chain-stores. This would therefore introduce an endogenous sunk cost. As in Sutton (1991), in larger markets chain-stores could compete more intensely by escalating expenditure on quality enhancement. Dinlersoz goes on to explain that this would support the findings of his model as, like with a lower chain-store price, higher quality chain-stores result in a reduction in the segment of

\footnotetext{
${ }^{30}$ This result is robust to various sensitivity tests (see Appendix A) involving the exclusion of: Scrivens, Optical Express and Rayner outlets from the definition of independent retailers (Table 7.1); the largest $10 \%$ of markets (7.2) or all London LADs (7.3).

${ }^{31} \mathrm{In}$ contrast, if the number of major retail grants is included instead or in addition, this has no significant effect.

${ }^{32}$ In addition, if either the density or travel variables are included their coefficients were insignificant.
} 
the market served by independents. Consequently, the predictions of the Dinlersoz model for the number of independent retailers would remain similar to those described in section 2.3. However, this impact of chain-store quality escalation could also occur under national pricing. In contrast, our above finding on the relationship between the number of independents and market size suggests that such quality escalation does not play an important role in this market. Instead the results suggest that, like prices, chain-store quality levels are determined at a national level, with little role for local differential levels of non-price competition.

\section{A comparison of markets with and without chain-stores}

The preceding analysis has been confined to markets in which one or more chain-store is present. However, unlike in Dinlersoz's study, here there are also a number of markets where no chain-stores are present and these provide a useful comparator for assessing the impact of chain-store presence.

First, we examine the likelihood that at least one chain-store is present in a local market. Assume the likelihood that one or more chain-store enters market $i\left(z_{i}^{*}\right)$ is given by

$$
z_{i}^{*}=X_{i}^{\prime} \gamma+u_{i}
$$

where $X_{i}$ is a vector of demographic variables for market $i$ and $u_{i}$ is an error term. However, we only observe the binary decision $\left(z_{i}\right)$ of at least one chainstore to entry market $i$. We can write the likelihood that we observe at least 
one chain-store in market $i\left(z_{i}=1\right)$ as:

$$
z_{i}=\left\{\begin{array}{l}
1 \text { if } z_{i}^{*}>0 \\
0 \text { otherwise }
\end{array}\right.
$$

If we assume the error term $\left(u_{i}\right)$ is normally distributed then the probability that at least one chain-store enters market $i$ can be estimated using a probit model. Table 8 reports the results from estimating this model for our full sample of markets.

[Table 8 here]

This shows, as we would expect, that chain-stores are more likely to be present in the larger markets and those where people working in the area have typically travelled further to do so. As for independent outlets, a higher proportion of income support claimants also has a positive impact on the likelihood of chain-store presence, supporting the earlier suggestion that demand is higher in such districts. Interestingly, in contrast to for independents, both the age and wage of the population are insignificant. This is consistent with a degree of product differentiation between the two retail sectors. Finally, a larger number of major retail developments in the area increases the likelihood that chain-stores will be present.

We can now estimate the specification in (8) for our full sample of markets and allow for the possibility that chain-store presence in the market affects both the number of independents directly and the relationship between the 
number of independents and market size:

$\log \left(\right.$ NInds $\left._{i}\right)=C+\alpha \log \left(\right.$ Population $\left._{i}\right)+X_{i}^{\prime} \beta+$ dumchain $_{i}+\sigma$ dumchain $_{i} * \log \left(\right.$ Population $\left._{i}\right)+\epsilon_{i}$

where dumchain du $_{i}$ is binary variable which equals one if at least one chainstore is present in market $i$.

We can use an estimate of the likelihood of chain-store presence to correct for the fact that chain-store presence is endogenously determined 33 . As discussed earlier, major retail sites are expected to be the prime location for chain-store opticians, whereas independents are primarily located in smaller premises. Furthermore, as Sadun (2013) demonstrates, variation in planning permission is determined by the political affiliations of the local council. This helps to alleviate concerns that the number of planning grants accepted is highly correlated with unobserved local demand and cost conditions 34 . Therefore, we use variation in the number of previously accepted major retail planning grants as an instrument for chain-store presence. In Table 9 we report the results from jointly estimating (9) and (10) with a treatment effects mode ${ }^{35}$ using full maximum likelihood ${ }^{36}$,

[Table 9 here]

\footnotetext{
${ }^{33}$ See Greene (2003, p.788) for a formal description of the correction procedure.

${ }^{34}$ In addition, the lag in the planning data also alleviates concerns that political affiliation is in turn highly correlated with the local market conditions. Sadun (2013) uses the number of major planning grants as a measure of the entry (in any sector) of large retailers. Then, using political affiliation as an instrument, estimates the impact of such entry on employment by small retailers.

${ }^{35}$ Brown and Mergoupis (2010) show that this procedure also consistently estimates the interaction term in (10).

${ }^{36}$ This uses information on the joint distribution of Ninds and dumchain (see Maddala, 1983, pp. 120-2.)
} 
Here, the estimates on the determinants of chain-store presence are very similar to those for the probit regression reported in Table $8^{37}$. For the independent retailers, there is no evidence that the sum of the coefficients on $\log ($ Population $)$ and dumchain* $\log ($ Population $)$ is less than one. Therefore, consistent with our earlier findings, in markets where chain-stores are present the number of independent retailers increases in proportion with an increase in market size. In contrast, a one tailed t-test suggests that the coefficient on $\log ($ Population $)$ is less than one $(p=0.06)$ i.e. in markets where no chain-store is present the number of independents increases less than proportionately with an increase in market size 38

The $\rho$ parameter reported in Table 9 measures the correlation between the error terms in (9) and (10). Therefore, this captures the extent to which failing to account for the endogeniety of chain-store presence by estimating the equations jointly results in bias. However, a likelihood ratio test cannot reject the null hypothesis that $\rho=0$ and so suggests that (9) and (10) are independent. Table 10.1 in Appendix B shows that the above results are very similar if we estimate the equation for independents using OLS. In particular, the coefficient on $\log$ (Population) is less than one $(p<0.05)^{39}$,

\footnotetext{
${ }^{37}$ All the results in Table 9 also remain very similar if the wage and age variables are left out from the chain-store equation.

${ }^{38}$ If we instead estimate (10) by the alternative two-step procedure which uses the probit estimation to correct for the endogeniety, whilst the coefficients remain similar in magnitude, dumchain and the interaction with market size are no longer significant at the $10 \%$ level.

${ }^{39}$ Appendix B shows that this result is robust to the same sensitivity tests as earlier i.e. the exclusion of: Scrivens, Optical Express and Rayner outlets from the definition of independent retailers (Table 10.2); the largest $10 \%$ of markets (10.3) or all London LADs (10.4). In particular, when a narrower definition of an independent retailer is used there is stronger evidence that the coefficient on $\log ($ Population $)<1$. Additional results (available on request) suggest that when (9) and (10) are estimated jointly for these reduced samples, they are again independent.
} 
Overall, these results confirm that for markets where chain-stores are present 40 , the relationship between the number of independents and market size predicted under chain-store national pricing and identified in the empirical analysis in section 4 continues to hold. In contrast, in markets with no chain-stores, there is some evidence to suggest that the number of independent outlets increases less than proportionately with an increase in market size. Interestingly, this suggests that when no chain-store is present, competitive intensity between independents may increase as the number of independents goes up. Therefore, this differs from the predictions of the model developed in section 2, which focused on markets where chain-stores were also present. It follows that the way in which independent retailers were modelled may only be valid when chain-stores are also present and that an alternative model may be more appropriate for other markets. The difference in competitive conduct and market outcomes across these different markets clearly merits further investigation.

\section{Conclusion}

The findings of this paper suggest that in the retail opticians' market England independent outlets appear to have been sheltered from the negative impact

\footnotetext{
${ }^{40}$ In additional estimations, we added further interaction terms into (10) to test for the possibility that the number of independent retailers is also affected by the precise number of chain-store outlets or fascias present. However, the results (available on request) suggest that this is not the case. Instead, it is whether or not there is a chain-store present that seems to be important. This is consistent with the theoretical model described in section 2, under national pricing. In addition, given the evidence suggesting that the Specsavers chain acts as an industry price leader (see section 2.2 ), we have also looked into whether it is in fact the presence of this chain that has a key effect on independents. However, this appears to not be the case, again supporting the evidence that it is the presence of any chain that is important.
} 
chain-store competition could have had on them. Two complementary explanations for this are provided 41 Firstly, the national pricing strategies adopted by chain-stores would appear to dampen the impact their entry has on independents. Secondly, the results suggest that in this market chainstores and independent retailers appeal to different segments of the market. In particular, independents appeal more to both the elderly and higher earning consumers.

The first of these explanations implies that the chain-stores' decisions to adopt national pricing policies result in an increased variety of retailers and consequently may be beneficial to consumers. However, one explanation for national pricing strategies not allowed for in the theoretical literature so far, is the possibility that it facilitates coordination, in particular by increasing price transparency 42 . In contrast, the Dobson and Waterson model described earlier is in a one-shot setting in which the chain-store has a unilateral incentive to dampen competition. If coordination is facilitated, then the benefits to consumers from national pricing become far less clear. R elatedly, Busse (2000) uses detailed price data to suggest that by setting identical prices across certain markets mobile telephone sellers in the US are able to establish focal prices and coordinate their actions. Therefore, it would be worthwhile to examine whether national pricing could also aid coordination

\footnotetext{
${ }^{41}$ This finding is also supported by the OFT (2009, para 26) who conclude that there is no evidence to indicate that over time competition from chain-stores has lead to a reduction in the number of independent opticians. Evidence is even provided that the other opticians have gained market share at the expense of the four main players (para. $39)$.

${ }^{42} \mathrm{~A}$ similar concern was also raised in a more recent Competition Commission investigation of the UK groceries market since, contrary to the period of the earlier investigation discussed in the introduction, most of the main players had by then adopted national pricing strategies (see Competition Commission (2008), paras. 4.98 and 8.25).
} 
in the retail opticians' market. 


\title{
Appendices
}

\section{A Robustness of the Results in Table 6}

\author{
[Table 7 here]
}

\section{B Robustness of the Results in Table 9}

\author{
[Table 10 here]
}

\section{References}

Association of Convenience Stores, 2006, Competition Commission - Grocery market investigation, issues paper from the Association of Convenience Stores, Association of Convenience Stores.

Borraz F., J. Dubra, D. Ferrés, L. Zipitría, 2013, "Supermarket entry and the survival of small stores", Review of Industrial Organization, 44(1), 73-93.

Bresnahan, T.F. and P. C. Reiss, 1991, "Entry and competition in concentrated markets", Journal of Political Economy, 99, 977-1009.

Brown, G., and T. Mergoupis, 2010, "Treatment Interactions with NonExperimental Data in Stata", Bath Economics Research Papers, No. 10/10. http://www.bath.ac.uk/economics/research/working-papers/ 2010-papers/10-10.pdf

Burt, S. and L. Sparks, 2003, Department of Trade and Industry: Competitive analysis of the retail sector in the UK, Institute for Retail Studies, University of Stirling, Scotland.

Busse, M.R., 2000, "Multimarket contact and price coordination in the cellular telephone industry", Journal of Economics and Management Strategy, 9 (3), 287-320. 
Cleeren, K., M.G. Dekimpe, K. Gielens and F. Verboven, 2008, "Intraand inter-format competition among discounters and supermarkets", Marketing Science, 29 (3), 456-73.

Competition Commission, 2000, A report on the supply of groceries from multiple stores in the United Kingdom, CM 4842, TSO: London.

Competition Commission, 2008, The supply of groceries in the UK market investigation, http://www. competition-commission.org.uk/rep_pub/ reports/2008/fulltext/538.pdf

Dalkir, S. and F.R. Warren-Boulton, 1999, "Prices, market definition and the effects of merger: Staples-Office Depot (1997)" in: Kwoka, Jr., J.E. and L.J. White (eds.), The Antitrust Revolution, 3rd edition, OUP, 143163.

Davies, S. W., H. Coles, M. Olczak, C. Pike, and C. Wilson, 2004, The benefits from competition: some illustrative UK cases, DTI Economics Paper, No.9.

Dinlersoz, E.M., 2004, "Firm organization and the structure of retail markets", Journal of Economics and Management Strategy, 13, 207-40.

Dobson, P. and M. Waterson, 2005, "Chain-store pricing across local markets", Journal of Economics and Management Strategy, 14, 93-120.

Fulop, C. and K. Warren, 1993, "Deregulation and its impact on the opticians' market: a comparison of the forecasts of both proponents and opponents with events in practice", International Journal of Advertising, 12, 257-78.

Greene, W. H., 2003, Econometric Analysis, (5th ed.). Upper Saddle River, N.J.: Prentice Hall.

Griffith, R. and H. Harmgart, 2012, "Supermarkets and planning regulation", The International Review of Retail, Distribution and Consumer Research, 22 (1), 1-25.

House of Commons, All-Party Parliamentary Small Shops Group, 2006, High-street Britain: 2015.

Igami, M., 2011, "Does big drive out small? Entry, exit and differentiation in the supermarket industry", Review of Industrial Organization, 38, $1-21$. 
Jia, P., 2008, "What happens when Wal-Mart comes to town: an empirical analysis of the discount retailing industry", Econometrica, 76 (6), 1263316.

Keynote, 2002, Ophthalmic Goods and Services, Market report, Keynote.

Maddala, G. S., 1983, Limited-dependent and qualitative variables in econometrics, Cambridge: Cambridge University Press.

New Economics Foundation, 2005, Clone town Britain: the survey of results on the bland state of the nation, New Economics Foundation.

Office of Fair Trading (OFT), 2009, Proposed joint venture between Alliance Boots Limited and Dolland and Aitchison Limited in relation to their respective optical businesses, ME/4014/09 http://www.oft.gov.uk/ shared_oft/mergers_ea02/2009/Alliance_Boots.pdf

Sadun, R., 2013, "Does planning regulation protect independent retailers?", Working Paper. http://www.hbs.edu/faculty/Publication\% 20Files/12-044_bbe12488-f9a7-42d4-93dc-7b888a87faf0.pdf

Sobel, R.S. and M. Dean, 2008, "Has Wal-Mart buried mom and pop? The impact of Wal-Mart on self-employment and small establishments in the United States", Economic Inquiry, 46 (4), 676-95.

Sutton, J., 1991, Sunk Costs and Market Structure: Price Competition, Advertising and the Evolution of Concentration, MIT Press, Cambridge, MA.

Toivanen, T. and M. Waterson, 2005, "Market structure and entry: where's the beef?", RAND Journal of Economics, 36 (3), 680-99. 
Figure 1: The number of opticians' outlets by LAD population $(S)$

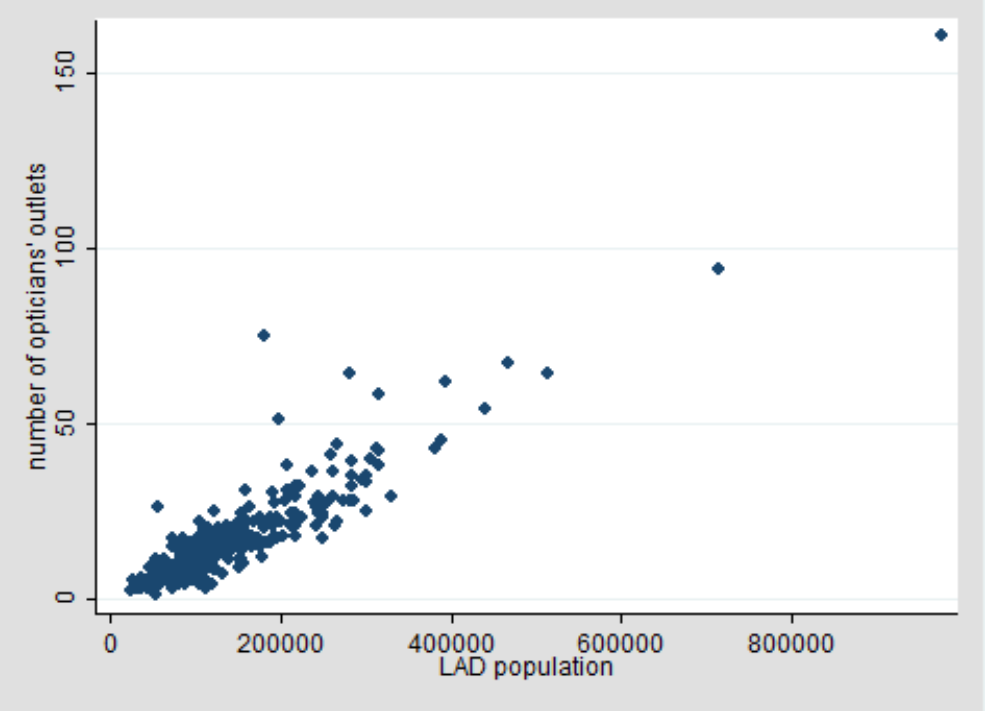

Table 1: The largest multi-store opticians in England

\begin{tabular}{cc}
\hline Retailer & Number of outlets \\
\hline \hline Specsavers & 383 \\
Dolland and Aitchison & 328 \\
Boots & 261 \\
Vision Express & 166 \\
\hline Scrivens & 105 \\
Optical Express & 101 \\
Rayner & 73 \\
Batemans & 54 \\
Leightons & 43 \\
Others & 4303 \\
\hline
\end{tabular}


Table 2: Retailer presence across regions of England

\begin{tabular}{c|cc}
\hline Retailer & \multicolumn{2}{|c}{$\begin{array}{c}\text { Number of regions in which } \\
\text { 1 or more outlet }\end{array}$} \\
& 9 & or more outlets \\
\hline \hline Specsavers & 9 & 9 \\
Dolland and Aitchison & 9 & 9 \\
Boots & 9 & 9 \\
Vision Express & 7 & 7 \\
\hline Scrivens & 9 & 9 \\
Optical Express & 8 & 6 \\
Rayner & 2 & 2 \\
Batemans & 6 & 3 \\
Leightons &
\end{tabular}

Table 3: The number of opticians' outlets by LAD market

\begin{tabular}{c|cccc}
\hline & Mean & Std Dev & Min & Max \\
\hline \hline Total & 16.67 & 14.09 & 1 & 161 \\
\hline Chain-store fascias & 2.50 & 1.41 & 0 & 4 \\
Chain-store outlets & 3.26 & 2.44 & 0 & 21 \\
\hline Inds & 13.41 & 12.38 & 1 & 140 \\
\hline Specsavers & 1.10 & 0.82 & 0 & 5 \\
Dolland and Aitchison & 0.94 & 1.06 & 0 & 9 \\
Boots & 0.75 & 0.71 & 0 & 4 \\
Vision Express & 0.48 & 0.56 & 0 & 3
\end{tabular}


Table 4: Population in markets with and without chain-store outlets

\begin{tabular}{c|ccccc}
\hline N Chain-stores & LAD Mkts & Mean & Min & Max & Std Dev \\
\hline \hline$>0$ & 308 & 148470 & 25949 & 977087 & 95716 \\
0 & 41 & 75421 & 24457 & 121024 & 25135 \\
\hline All & 349 & 139888 & 24457 & 977087 & 93325
\end{tabular}

Table 5: Demographic variables

\begin{tabular}{|c|c|c|c|c|c|}
\hline Variable & Description & Mean & Std Dev & Min & Max \\
\hline Population & $\begin{array}{l}\text { LAD population (number of } \\
\text { people) }\end{array}$ & 139888 & 93325 & 24457 & 977087 \\
\hline Major grants & $\begin{array}{l}\text { Total number of major } \\
\text { planning grants accepted } \\
1997-2003\end{array}$ & 18.71 & 17.66 & 0 & 123 \\
\hline Minor grants & $\begin{array}{l}\text { Total number of minor plan- } \\
\text { ning grants accepted } 1997 \text { - } \\
2003\end{array}$ & 232.55 & 255.19 & 1 & 3134 \\
\hline Density & $\begin{array}{l}\text { Number of people per } \\
\text { hectare }\end{array}$ & 14.03 & 20.18 & 0.23 & 131.02 \\
\hline Age & $\begin{array}{l}\text { Mean age of LAD popula- } \\
\text { tion (years) }\end{array}$ & 39.25 & 2.34 & 31.75 & 46.85 \\
\hline Wage & $\begin{array}{l}\text { Mean weekly wage of LAD } \\
\text { population excluding over- } \\
\text { time }(£)\end{array}$ & 413.56 & 94.97 & 237.4 & 1136.5 \\
\hline Inc support & $\begin{array}{l}\% \text { of LAD population claim- } \\
\text { ing income support }\end{array}$ & 5.94 & 2.41 & 1.85 & 15.01 \\
\hline Travel & $\begin{array}{l}\% \text { of people working in the } \\
\text { LAD that travel } 20+\mathrm{km} \text { to } \\
\text { work }\end{array}$ & 11.73 & 4.44 & 2.83 & 31.75 \\
\hline
\end{tabular}


Table 6: The relationship between the number of independent outlets and market size when chain-stores are present

\begin{tabular}{c|l}
\hline & $\log ($ NInds $)$ \\
\hline \hline Constant & $-18.570^{* * *}$ \\
$\log$ (Population) & $1.013^{* * *}$ \\
& $(0.053)$ \\
Minor grants & $0.00036^{* * *}$ \\
& $(0.0001)$ \\
$\log$ (Age) & $1.801^{* * *}$ \\
& $(0.419)$ \\
$\log ($ Wage $)$ & $0.369^{* * *}$ \\
& $(0.125)$ \\
Inc support & $0.029 * *$ \\
& $(0.011)$ \\
\hline $\mathrm{N}$ & 308 \\
Adj $R^{2}$ & 0.72
\end{tabular}

***Significantly different from 0 at $1 \%$ level, ** significantly different from 0 at $5 \%$ level and ${ }^{*}$ significantly different from 0 at $10 \%$ level. Standard errors in parenthesis. 
Table 7: The relationship between the number of independent outlets and market size when chain-stores are present

\begin{tabular}{c|l|l|l}
\hline & 1 & 2 & 3 \\
\hline \hline \multirow{2}{*}{ Constant } & $\log ($ NInds $)$ & $\log ($ NInds $)$ & $\log ($ NInds $)$ \\
\hline \multirow{3}{*}{$\log$ (Population) } & $(2.158)$ & $(2.343)$ & $(2.358)$ \\
& $1.001^{* * *}$ & $0.965^{* * *}$ & $1.015^{* * *}$ \\
Minor grants & $(0.052)$ & $(0.065)$ & $(0.065)$ \\
& $0.00033^{* * *}$ & $0.00034^{* * *}$ & $0.00042^{* * *}$ \\
$\log$ (Age) & $(0.0001)$ & $(0.0001)$ & $(0.0002)$ \\
$\log$ (Wage) & $2.042^{* * *}$ & $1.749^{* * *}$ & $1.755^{* * *}$ \\
& $(0.414)$ & $(0.443)$ & $(0.455)$ \\
Inc support & $0.477^{* * *}$ & $0.444^{* * *}$ & $0.347^{* *}$ \\
& $(0.124)$ & $(0.136)$ & $(0.172)$ \\
& $0.035^{* * *}$ & $0.029^{* *}$ & 0.023 \\
N & $(0.011)$ & $(0.013)$ & $(0.015)$ \\
Adj $R^{2}$ & 307 & 277 & 276 \\
& 0.72 & 0.59 & 0.70
\end{tabular}

***Significantly different from 0 at $1 \%$ level, ** significantly different from 0 at $5 \%$ level and ${ }^{*}$ significantly different from 0 at $10 \%$ level. Standard errors in parenthesis. 
Table 8: The likelihood of chain-store presence in a local market

\begin{tabular}{c|l}
\hline & dumchain \\
\hline \hline Constant & $-26.308^{* *}$ \\
$\log$ (Population) & $12.583)$ \\
& $(0.359)$ \\
Major grants & $0.027^{* * *}$ \\
& $(0.014)$ \\
$\log ($ Density) & 0.217 \\
& $(0.132)$ \\
$\log$ (Age) & 2.961 \\
$\log$ (Wage) & $(2.833)$ \\
& -0.230 \\
Inc support & $0.262^{* * *}$ \\
Travel & $(0.101)$ \\
& $0.141^{* * *}$ \\
Pog likelihood & $(0.040)$ \\
\hline N & 349 \\
& 0.33 \\
\hline
\end{tabular}

***Significantly different from 0 at $1 \%$ level, ** significantly different from 0 at $5 \%$ level and ${ }^{*}$ significantly different from 0 at $10 \%$ level. Standard errors in parenthesis. 
Table 9: Joint maximum likelihood estimation of the number of independents and chain-store presence

\begin{tabular}{|c|c|c|}
\hline & dumchain & $\log ($ NInds $)$ \\
\hline \multirow[t]{2}{*}{ Constant } & $-26.186^{* *}$ & $-15.336^{* * *}$ \\
\hline & $(12.665)$ & $(2.770)$ \\
\hline \multirow[t]{2}{*}{$\log$ (Population) } & $1.271^{* * *}$ & $0.739 * * *$ \\
\hline & $(0.360)$ & $(0.164)$ \\
\hline \multirow[t]{2}{*}{ Major grants } & $0.027^{*}$ & \\
\hline & $(0.014)$ & \\
\hline \multirow[t]{2}{*}{ Minor grants } & & $0.0004^{* * *}$ \\
\hline & & $(0.0001)$ \\
\hline \multirow[t]{2}{*}{$\log ($ Density $)$} & 0.217 & \\
\hline & $(0.132)$ & \\
\hline \multirow[t]{2}{*}{$\log ($ Age $)$} & 2.915 & $1.752^{* * *}$ \\
\hline & $(2.848)$ & $(0.414)$ \\
\hline \multirow[t]{2}{*}{$\log$ (Wage) } & -0.239 & $0.376^{* * *}$ \\
\hline & $(0.906)$ & $(0.124)$ \\
\hline \multirow[t]{2}{*}{ Inc support } & $0.261^{* * *}$ & $0.025 * *$ \\
\hline & $(0.101)$ & $(0.012)$ \\
\hline \multirow[t]{2}{*}{ Travel } & $0.140^{* * *}$ & \\
\hline & $(0.041)$ & \\
\hline \multirow[t]{2}{*}{ dumchain } & & $-3.167^{*}$ \\
\hline & & $(1.858)$ \\
\hline \multirow[t]{2}{*}{ dumchain* $\log$ (Population) } & & $0.281^{*}$ \\
\hline & & $(0.167)$ \\
\hline $\mathrm{N}$ & 349 & \\
\hline$\rho$ & 0.050 & \\
\hline & $(0.142)$ & \\
\hline Wald $\chi^{2}$ & $877.81^{* * *}$ & \\
\hline
\end{tabular}

***Significantly different from 0 at $1 \%$ level, ** significantly different from 0 at $5 \%$ level and ${ }^{*}$ significantly different from 0 at $10 \%$ level. Standard errors in parenthesis. 
Table 10: The relationship between the number of independent outlets and market size for all markets

\begin{tabular}{|c|c|c|c|c|}
\hline & 1 & 2 & 3 & 4 \\
\hline & $\log (N I n d s)$ & $\log (N I n d s)$ & $\log (N I n d s)$ & $\log (N I n d s)$ \\
\hline Constant & $\begin{array}{l}-15.175^{* * *} \\
(2.765)\end{array}$ & $\begin{array}{l}-16.346^{* * *} \\
(2.720)\end{array}$ & $\begin{array}{l}-15.048^{* * *} \\
(2.839)\end{array}$ & $\begin{array}{l}-14.888^{* * *} \\
(2.908)\end{array}$ \\
\hline $\log$ (Population) & $\begin{array}{l}0.721^{* * *} \\
(0.158)\end{array}$ & $\begin{array}{l}0.696^{* * *} \\
(0.155)\end{array}$ & $\begin{array}{l}0.718^{* * *} \\
(0.160)\end{array}$ & $\begin{array}{l}0.714^{* * *} \\
(0.161)\end{array}$ \\
\hline Minor grants & $\begin{array}{l}0.0004^{* * *} \\
(0.0001)\end{array}$ & $\begin{array}{l}0.0003^{* * *} \\
(0.0001)\end{array}$ & $\begin{array}{l}0.0004^{* * *} \\
(0.0001)\end{array}$ & $\begin{array}{l}0.0005^{* * *} \\
(0.0002)\end{array}$ \\
\hline $\log ($ Age $)$ & $\begin{array}{l}1.759^{* * *} \\
(0.418)\end{array}$ & $\begin{array}{l}1.967^{* * *} \\
(0.411)\end{array}$ & $\begin{array}{l}1.717^{* * *} \\
(0.431)\end{array}$ & $\begin{array}{l}1.730^{* * *} \\
(0.452)\end{array}$ \\
\hline log(Wage) & $\begin{array}{l}0.375^{* * *} \\
(0.126)\end{array}$ & $\begin{array}{l}0.476^{* * *} \\
(0.124)\end{array}$ & $\begin{array}{l}0.385^{* * *} \\
(0.133)\end{array}$ & $\begin{array}{l}0.360^{* *} \\
(0.168)\end{array}$ \\
\hline Inc support & $\begin{array}{l}0.025^{* *} \\
(0.012)\end{array}$ & $\begin{array}{l}0.031^{* * *} \\
(0.011)\end{array}$ & $\begin{array}{l}0.025^{* *} \\
(0.012)\end{array}$ & $\begin{array}{l}0.019 \\
(0.015)\end{array}$ \\
\hline dumchain & $\begin{array}{l}-3.290^{*} \\
(1.848)\end{array}$ & $\begin{array}{l}-3.427^{*} \\
(1.818)\end{array}$ & $\begin{array}{l}-3.093 \\
(1.908)\end{array}$ & $\begin{array}{l}-3.357^{*} \\
(1.912)\end{array}$ \\
\hline dumchain* ${ }^{*} \log ($ Population $)$ & $\begin{array}{l}0.294^{*} \\
(0.165)\end{array}$ & $\begin{array}{l}0.306^{*} \\
(0.162)\end{array}$ & $\begin{array}{l}0.277 \\
(0.170)\end{array}$ & $\begin{array}{l}0.300^{*} \\
(0.170)\end{array}$ \\
\hline $\mathrm{N}$ & 349 & 348 & 331 & 317 \\
\hline $\operatorname{Adj} R^{2}$ & 0.71 & 0.71 & 0.63 & 0.69 \\
\hline
\end{tabular}

***Significantly different from 0 at $1 \%$ level, ** significantly different from 0 at $5 \%$ level and * significantly different from 0 at $10 \%$ level. Standard errors in parenthesis. 